\title{
EVALUASI PERTUMBUHAN BENIH PATIN (Pangasius hypophthalmus) YANG DIBERI PAKAN TAMBAHAN CACING SUTRA (Tubifex sp.)
}

\section{EVALUATION OF GROWTH OF PATIN SEED THAT GIVEN Tubifex sp. AS ADDITIONAL FEED}

\author{
Dini Islama $^{1}$, Nurul Najmi ${ }^{2}$, Nurhatijah ${ }^{3}$, Yusi Maisara ${ }^{4}$ \\ ${ }^{1}$ Program Studi Akuakultur, Fakultas Perikanan dan Ilmu Kelautan, Universitas Teuku Umar \\ ${ }^{2}$ Program Studi Sumber Daya Akuatik, Fakultas Perikanan dan Ilmu Kelautan, Universitas Teuku \\ Umar \\ ${ }^{3}$ Program Studi Teknologi Produksi Benih dan Pakan Ikan, Politeknik Indonesia Venezuela \\ ${ }^{4}$ Mahasiswa Program Studi Teknologi Produksi Benih dan Pakan Ikan, Politeknik Indonesia \\ Venezuela \\ *Korespondensi : diniislama@utu.ac.id
}

\begin{abstract}
This study aimed to evaluate of patin seed (Pangasius hypothalamus) that is given Tubifex sp. as additional feed. The experiment design was used completely randomized design with four treatments and four replications. The treatments studied were $100 \%$ pellet without the addition of Tubifex sp. (A), $95 \%$ pellet with the addition of Tubifex sp. $5 \%$ (B), $90 \%$ pellet with the addition of Tubifex sp. $10 \%(C)$ and $85 \%$ pellet with the addition of Tubifex sp. $15 \%(D)$. Patin seed stocking density was 1 individu/l with the length of 3-4 cm and weight of 0,15$0,28 \mathrm{~g}$. The culture period for one cycle of fish farming was 40 days. The ANOVA test showed commercial feeding with the addition of Tubifex sp. as additional feed gave the significant effect on the specific of growth rate, length and feed conversion ratio, but did not give the significant effect on survival rate of patin seed. The best dose to increase the growth of catfish seeds is $85 \%$ commercial feeding with the addition of Tubifex sp. $15 \%$.
\end{abstract}

Keyword: Growth, Patin, Pellet, Tubifex sp.

\section{Pendahuluan}

Ikan patin (Pangasianodon hypophthalmus) merupakan salah satu spesies ikan air tawar yang memiliki nilai ekonomis tinggi dan sangat diminati oleh masyarakat Indonesia. Kegemaran masyarakat terhadap ikan patin dikarenakan kandungan nilai protein pada daging ikan patin cukup tinggi, serta memiliki tekstur dan rasa daging yang khas. Nilai protein daging ikan patin yaitu 68,6 \% protein, 5,8 \% lemak, 3,5\% abu dan 59,3\% air (Saparinto dan Susiana, 2014). Ikan patin memiliki pangsa pasar yang cukup baik di pasar domestik maupun pasar ekspor. Pada pasar domestik, tingkat permintaan ikan patin tertinggi terdapat di wilayah Jawa, Sumatera dan Kalimantan, sedangkan untuk pasar ekspor meliputi kawasan Amerika dan Eropa (Darmawan et al., 2016). Ikan ini berpotensi besar sebagai komoditas ekspor karena memiliki daging berwarna putih yang disukai oleh konsumen di luar negeri seperti Amerika Serikat dan Eropa (Hadinata, 2009).

Pakan merupakan salah satu faktor penting yang harus diperhatikan dalam kegiatan budidaya perikanan karena sumber energi utama bagi ikan berasal dari 
pakan. Ketersediaan pakan yang memenuhi kebutuhan nutrisi ikan akan menunjang pertumbuhannya, sehingga usaha dan produksi budidaya perikanan menjadi lebih optimal. Usaha budidaya ikan sangat bergantung pada pakan buatan, dimana harga pakan buatan relatif mahal menyebabkan biaya produksi meningkat sehingga keuntungan yang diperoleh pembudidaya semakin berkurang (Muchlisin et al., 2016). Pemberian pakan alami sebagai pakan tambahan dapat dijadikan alternatif untuk mengurangi penggunaan pakan buatan pada kegiatan produksi budidaya perikanan, sehingga pembudidaya dapat menghemat biaya pakan. Salah satu jenis pakan alami yang dapat digunakan sebagai pakan tambahan adalah cacing sutra (Tubifex sp.) karena memiliki kandungan nutrisi yang tinggi untuk memacu pertumbuhan dan mudah dicerna oleh tubuh ikan. Sulmartiwi et al. (2003) dalam Bitaryanto dan Taufikurohmah (2013) menyatakan bahwa Tubifex sp. memiliki kandungan nutrisi berupa protein $57 \%$, karbohidrat $2,04 \%$ dan lemak $13,3 \%$.

Beberapa hasil penelitian menunjukkan bahwa pemberian cacing sutra dapat meningkatkan pertumbuhan larva dan benih ikan patin diantaranya Idawati et al. (2018) yang menyatakan bahwa pemberian pakan Tubifex sp. merupakan perlakuan terbaik untuk pertumbuhan benih patin dengan nilai panjang sebesar $5,85 \mathrm{~cm}$ dan laju pertumbuhan spesifik 2,39\%/hari. Menurut Zarkasih (2015), pemberian Tubifex sp. menghasilkan pertumbuhan terbaik ikan patin dengan ratarata panjang mutlak sebesar $12,49 \mathrm{~cm}$ dan rata-rata pertambahan berat sebesar 12,12 g. Jusadi et al. (2015) menyebutkan bahwa larva ikan patin yang diberi cacing sutra dan kombinasi cacing sutra dengan pakan buatan memiliki tingkat kelangsungan hidup dan panjang akhir yang sama tinggi, sedangkan larva yang diberikan pakan buatan saja menunjukkan kelangsungan hidup dan panjang akhir yang sangat rendah.

Pemberian jenis pakan dan dosis yang tepat sangat berpengaruh terhadap pertumbuhan ikan karena pakan dengan nutrisi seimbang akan menunjang pertumbuhannya. Dengan memberikan Tubifex sp. sebagai pakan tambahan diharapkan mampu menyeimbangkan nutrisi yang tidak diperoleh benih patin pada pakan komersil. Selain itu, pemberian pakan alami sebagai pakan tambahan juga merupakan salah satu solusi untuk menghemat biaya pakan tanpa mengesamping keseimbangan nutrisi yang dibutuhkan oleh ikan. Penelitian ini bertujuan untuk untuk mengevaluasi pertumbuhan benih patin (Pangasius hypopthhalmus) yang diberi pakan tambahan cacing sutera (Tubifex sp.).

\section{Metode Penelitian}

\section{Waktu dan Tempat}

Penelitian ini dilaksanakan pada bulan Juni sampai dengan Juli 2018 di laboratorium pembenihan dan produksi pakan ikan pada Program Studi Teknologi Produksi Benih dan Pakan Ikan, Politeknik Indonesia Venezuela (Poliven). 


\section{Rancangan Percobaan}

Rancangan percobaan yang digunakan adalah Rancangan Acak Lengkap (RAL) non faktorial dengan empat perlakuan dan empat kali ulangan. Perlakuan yang diteliti yaitu pemberian pakan komersil $100 \%$ tanpa penambahan Tubifex sp. (A), pemberian pakan komersil $95 \%$ dengan penambahan Tubifex sp. $5 \%$ (B), pemberian pakan komersil $90 \%$ dengan penambahan Tubifex sp. $10 \%$ (C) dan pemberian pakan komersil $85 \%$ dengan penambahan Tubifex sp. $15 \%$ (D).

\section{Prosedur Penelitian}

\section{Wadah penelitian}

Wadah penelitian yang digunakan berupa toples plastik volume 20 liter sebanyak 16 buah. Wadah tersebut dicuci terlebih dahulu sebelum digunakan dan dikeringkan. Wadah yang telah bersih selanjutnya diisi air sebanyak 15 liter. Wadah dilengkapi dengan selang aerasi dan batu aerasi. Wadah ditempatkan di dalam ruangan sehingga terhindar dari sinar matahari langsung dan air hujan. Air yang digunakan sebagai media pemeliharaan berasal dari sumur.

\section{Biota uji}

Biota uji yang digunakan dalam penelitian ini adalah benih patin yang berukuran panjang berkisar 3-4 $\mathrm{cm}$ dan bobot berkisar 0,15-0,28 g. Jumlah total benih patin yang digunakan adalah 240 ekor, dengan padat tebar 1 ekor/l. Benih patin diperoleh dari Balai Benih Ikan Jantho, Aceh besar. Masa pemeliharaan benih patin berlangsung selama 40 hari.

\section{Pemberian pakan}

Pakan yang diberikan pada benih patin adalah pakan komersil berbentuk pasta dan cacing sutra (Tubifex sp.) beku sebagai pakan tambahan. Cacing sutra diberikan dengan cara direndam dalam air terlebih dahulu selama 5 menit. Pakan diberikan dua kali sehari pada pukul 08.00 WIB dan 16.00 WIB. Takaran pemberian cacing sutra (Tubifex sp.) sebagai pakan tambahan disesuaikan dengan perlakuan yang diteliti.

\section{Pengamatan Parameter}

Pengamatan parameter dilakukan dengan mengambil 50\% dari jumlah total benih patin pada masing-masing wadah penelitian. Pengambilan benih patin dilakukan dengan menggunakan serok halus, kemudian diletakkan dalam gelas ukur yang berisi air. Pengamatan tingkat kelangsungan hidup dilakukan setiap hari dengan mencatat jumlah ikan yang mati dari awal hingga akhir pemeliharaan. Untuk mengetahui pertumbuhan benih patin, maka dilakukan pengukuran panjang dan bobot benih patin setiap 10 hari sekali. Pengukuran panjang dilakukan dengan menggunakan penggaris dan pengukuran bobot dilakukan dengan menggunakan timbangan digital. 


\section{Parameter uji}

1. Tingkat Kelangsungan Hidup

Tingkat kelangsungan hidup dihitung berdasarkan formula Ricker (1979)

sebagai berikut:

$$
\mathrm{SR}=\frac{N t}{N o} \times 100 \%
$$

Keterangan :

$\mathrm{SR}=$ Sintasan/kelangsungan hidup $(\%)$

$\mathrm{Nt}=$ Jumlah benih ikan pada akhir percobaan (ekor)

No $=$ Jumlah benih ikan pada awal percobaan (ekor)

\section{Laju Pertumbuhan Spesifik}

Laju pertumbuhan spesifik dilakukan dengan menimbang sampel benih untuk mengetahui pertumbuhan bobot benih ikan terhadap pakan yang diberikan. Menurut Huisman (1987) dihitung dengan rumus sebagai berikut:

$$
\text { LPS }=\frac{L n W t-L n W o}{t} \times 100
$$

Keterangan :

LPS : Laju pertumbuhan bobot spesifik (\%/hari)

Wo : Bobot ikan awal penelitian (g)

Wt : Bobot ikan akhir penelitian (g)

$\mathrm{t}$ : Lama pemeliharaan (hari).

\section{Pertumbuhan Panjang Mutlak}

Pengukuran Panjang mutlak ikan menggunakan rumus pertumbuhan panjang menurut Effendie (1997) yaitu :

$$
\mathrm{PM}=\mathrm{Lt}-\mathrm{Lo}
$$

Keterangan:

$\mathrm{Pm} \quad=$ Pertumbuhan panjang mutlak $(\mathrm{cm})$

Lt $\quad=$ Panjang akhir ikan $(\mathrm{cm})$

Lo $\quad=$ Panjang awal ikan $(\mathrm{cm})$

\section{Rasio Konversi Pakan}

Rasio konverensi pakan adalah perbandingan antara jumlah pakan yang dikonsumsi dengan kenaikan bobot tubuh. Konverensi pakan dapat dihitung dengan menggunakan rumus sebagai Zonneveld et al. (1991) sebagai berikut:

$$
\mathrm{FCR}=\frac{\mathrm{KP}}{\Delta \mathrm{W}}
$$

Keterangan:

FCR = Rasio konverensi pakan

$\mathrm{KP} \quad=$ Jumlah total konsumsi pakan $(\mathrm{g})$

$\Delta \mathrm{W}=$ Pertambahan bobot $(\mathrm{g})$ 


\section{Analisis data}

Data yang diperoleh dianalisis menggunakan program microsoft excel 2010 dan SPSS 21.0, yang meliputi Analisis Sidik Ragam (ANOVA). Apabila berpengaruh nyata, untuk melihat perbedaan antar perlakuan akan diuji lanjut menggunakan uji Duncan dengan selang kepercayaan 95\%. Sedangkan data kualitas air dianalisis secara deskriptif.

\section{Hasil Dan Pembahasan Pertumbuhan}

Hasil evaluasi pertumbuhan benih patin yang diberikan pakan tambahan Tubifex sp. disajikan pada Gambar 1 dan Gambar 2. Selama 40 hari masa pemeliharaan, laju pertumbuhan bobot spesifik berkisar antara 1,12\% - 2,15\%, sedangkan pertumbuhan panjang mutlak berkisar antara 1,05 cm-2,28 cm. Hasil analisis sidik ragam menunjukkan bahwa pemberian pakan komersil dengan penambahan cacing sutra (Tubifex sp.) sebagai pakan tambahan berpengaruh nyata terhadap laju pertumbuhan bobot spesifik dan pertumbuhan panjang mutlak benih patin $(\mathrm{P}<0,05)$. Laju pertumbuhan bobot spesifik dan panjang mutlak tertinggi terdapat pada perlakuan D yaitu pemberian pakan komersil $85 \%$ dengan penambahan Tubifex sp. $15 \%$ sebesar $2,15 \%$ dan $2,28 \mathrm{~cm}$, sedangkan pertumbuhan bobot spesifik dan panjang mutlak terendah terdapat pada perlakuan A yaitu pemberian pakan komersil $100 \%$ tanpa penambahan Tubifex sp. dengan nilai sebesar $1,12 \%$ dan $1,05 \mathrm{~cm}$.

Pertumbuhan dapat dilihat dari adanya pertambahan panjang dan bobot ikan dalam kurun waktu tertentu. Pertumbuhan dapat dijadikan sebagai salah satu indikator bahwa pakan yang dimakan oleh ikan dapat terserap dengan baik oleh tubuh. Laju pertumbuhan bobok spesifik dan pertumbuhan panjang mutlak tertinggi pada perlakuan D diduga karena Tubifex sp. memiliki kandungan nutrisi yang tinggi untuk meningkatkan pertumbuhan benih patin, sehingga sangat cocok diberikan sebagai pakan tambahan. Menurut Sulmartiwi et al. (2003) dalam Bitaryanto dan Taufikurohmah (2013), Tubifex sp. memiliki kandungan nutrisi berupa protein $57 \%$, karbohidrat 2,04\% dan lemak 13,3\%. Kandungan protein dan lemak yang tinggi pada Tubifex sp. menjadi sumber energi utama yang digunakan oleh benih patin dalam menunjang pertumbuhannya. Selain itu, ukuran Tubifex sp. yang sesuai dengan bukaan mulut benih patin, warnanya yang kemerah-merahan dan aromanya yang khas akan merangsang ikan untuk memakannya. Hal ini terlihat dari respon benih patin yang sangat tertarik mengonsumsi Tubifex sp. yang diberikan sebagai pakan tambahan selama penelitian. Menurut Rachmawati dan Samidjan (2013), peningkatan bobot ikan disebabkan karena setiap pakan yang diberikan dapat direspon oleh ikan dan digunakan untuk proses metabolisme dan pertumbuhan, sehingga laju pertumbuhan menunjukkan kenaikan bobot ikan setiap harinya, sedangkan rendahnya laju pertumbuhan disebabkan karena pakan yang diberikan tidak mencukupi nilai gizi sehingga ikan tidak dapat merespon dengan baik. 


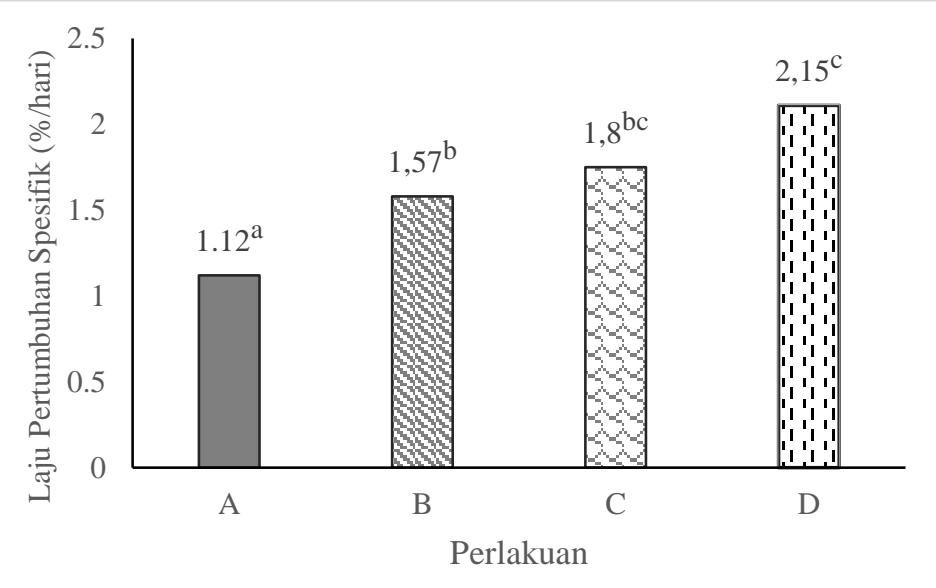

Gambar 1. Laju pertumbuhan bobot benih patin selama pemeliharaan.

Ket: Huruf supercript yang berbeda menunjukkan perbedaan yang nyata antar perlakuan pada taraf $5 \%$ uji Duncan

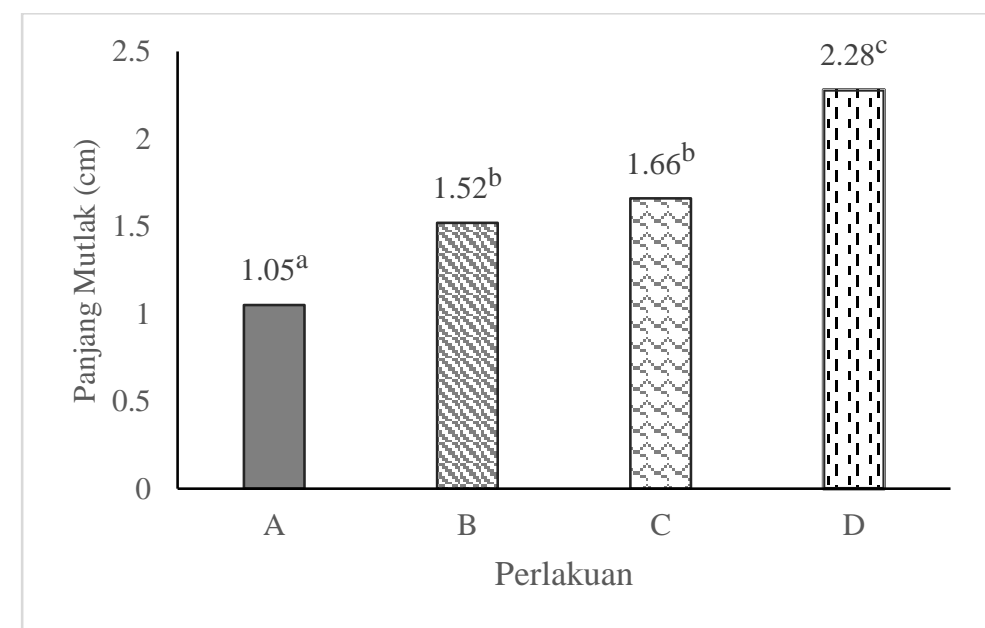

Gambar 2. Pertumbuhan panjang mutlak benih patin selama pemeliharaan Ket: Huruf supercript yang berbeda menunjukkan perbedaan yang nyata antar perlakuan pada taraf $5 \%$ uji Duncan

Pemberian pakan komersil $85 \%+$ Tubifex sp. $15 \%$ sebagai pakan tambahan merupakan kombinasi terbaik untuk meningkatkan pertumbuhan benih patin karena nutrisi dari pakan alami akan mendukung pakan komersil yang diberikan. Pakan komersil umumnya hanya mengandung protein $33 \%$, lemak $5 \%$ dan karbohidrat $6 \%$ (Mahyuddin, 2008). Nilai protein yang lebih rendah pada pakan komersil ini diduga menjadi penyebab benih patin menghasilkan pertumbuhan yang paling rendah pada perlakuan A (kontrol) dibandingkan perlakuan lainnya. Selain itu, tingkat pertumbuhan juga dipengaruhi oleh kemampuan daya cerna ikan terhadap pakan yang diberikan. Patin termasuk kedalam golongan karnivora yang cenderung lebih mudah mencerna protein dan lemak dibandingkan karbohidrat, sehingga pemberian pakan tambahan Tubifex sp. yang kaya akan nilai protein dan lemak secara bersamaan dengan pakan komersil akan mampu 
menghasilkan pertumbuhan lebih tinggi. Hal ini didukung oleh penelitian Bokings et al. (2017) yang menyatakan bahwa pemberian pakan buatan, cacing sutra (Tubifex sp.) dan kombinasi keduanya berpengaruh positif terhadap pertumbuhan dan kelangsungan hidup benih ikan patin. Penelitian Jusadi et al. (2015) juga menyatakan bahwa perlakuan kombinasi cacing sutra dan pakan buatan menunjukkan aktivitas lipase dan protease yang tinggi, sehingga menghasilkan pertumbuhan larva yang tinggi pula, sedangkan larva yang diberikan pakan buatan saja menghasilkan pertumbuhan larva yang sangat rendah.

\section{Rasio Konversi Pakan}

Hasil pengamatan rasio konversi pakan disajikan pada Gambar 3. Rasio konversi pakan berkisar antara 1,55 g - 2,42 g. Hasil analisis sidik ragam menunjukkan bahwa pemberian pakan komersil dengan penambahan cacing sutra (Tubifex sp.) sebagai pakan tambahan berpengaruh nyata terhadap rasio konversi pakan $(\mathrm{P}<0,05)$. Rasio konversi pakan tertinggi terdapat pada perlakuan pemberian pakan komersil $100 \%$ tanpa penambahan Tubifex sp. $5 \%$ (A) sebesar 2,42 g, sedangkan nilai terendah terdapat pada perlakuan pemberian pakan komersil $85 \%$ dengan penambahan cacing sutra (Tubifex sp.) $15 \%$ (D) sebesar $1,55 \mathrm{~g}$.

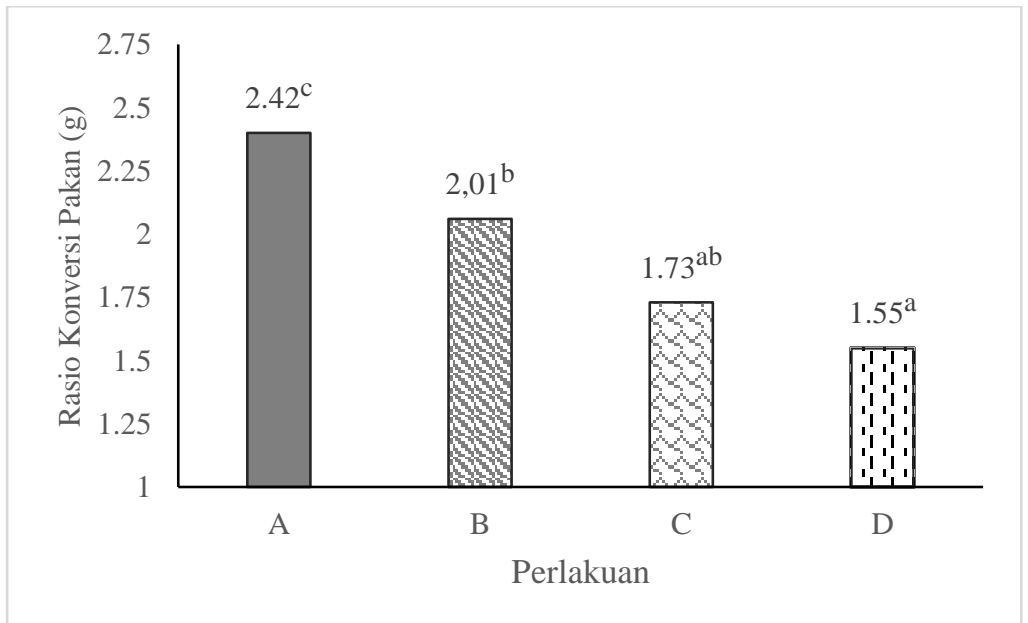

Gambar 3. Rasio konversi pakan

Ket: Huruf supercript yang berbeda menunjukkan perbedaan yang nyata antar perlakuan pada taraf $5 \%$ uji Duncan

Rasio konversi pakan dapat dijadikan sebagai salah satu indikator untuk melihat sejauh mana pakan yang diberikan mampu meningkatkan bobot ikan yang dipelihara dalam kurun waktu tertentu. Rendahnya konversi pakan berarti sesmakin tinggi efisiensi pakan tersebut dan sebaliknya semakin tinggi nilai konversi pakan maka semakin rendah efisiensinya (Saputra et al., 2018). Nilai rasio konversi pakan terendah sebesar $1,55 \mathrm{~g}$ pada perlakuan D diduga karena pemberian pakan komersil $85 \%$ dan Tubifex sp. $15 \%$ sebagai pakan tambahan mampu dimanfaatkan dan dicerna dengan baik oleh benih patin untuk 
meningkatkan pertumbuhannya. Hal ini berarti bahwa untuk menghasilkan bobot benih patin $1 \mathrm{~kg}$ dibutuhkan 1,55 kg pakan. Tekstur Tubifex sp. yang lunak karena tidak memiliki rangka skeleton diduga menjadi faktor pakan ini mudah dicerna oleh usus benih patin, sehingga bisa langsung diserap oleh tubuh dan dipergunakan untuk pertumbuhannya. Hal ini sesuai dengan Hanief et al. (2014) yang menyatakan bahwa konversi dan efisiensi pakan erat kaitannya dengan nilai kecernaan. Semakin besar nilai kecernaan suatu pakan maka semakin banyak nutrisi dalam pakan yang dimanfaatkan untuk pertumbuhan ikan.

Pada stadia benih, patin memiliki sistem pencernaan yang masih sederhana sehingga mengakibatkan usus belum mampu memproduksi enzim pencernaan secara cepat untuk mencerna protein pakan komersil. Hal inilah yang diduga menyebabkan nilai rasio konversi pakan paling tinggi terdapat pada perlakuan A. Selain itu, pakan komersil yang diberikan pada benih patin diduga memiliki kualitas yang kurang baik, dimana selama penelitian terlihat bahwa pakan yang diberikan cenderung mudah hancur di dalam air. Benih patin juga lebih terangsang untuk memakan Tubifex sp. dibandingkan pakan komersil karena memiliki aroma yang khas dan tekstur yang lunak. Menurut Arief et al. (2011), faktor yang mempengaruhi tingginya rasio konversi pakan adalah kualitas pakan yang kurang baik misalnya pakan yang mudah hancur atau bau pakan yang tidak merangsang akan menyebabkan pakan tidak termakan oleh ikan.

\section{Tingkat Kelangsungan Hidup}

Hasil pengamatan tingkat kelangsungan hidup benih patin yang diberikan pakan tambahan Tubifex sp. disajikan pada Gambar 4. Tingkat kelangsungan hidup benih patin selama 40 hari masa pemeliharaan berkisar antara $61,68 \%$ $76,67 \%$. Hasil analisis sidik ragam menunjukkan bahwa pemberian pakan komersil dengan penambahan cacing sutra (Tubifex sp.) sebagai pakan tambahan berpengaruh tidak nyata terhadap kelangsungan hidup benih patin $(\mathrm{P}>0,05)$. Kelangsungan hidup benih patin tertinggi terdapat pada perlakuan pemberian pakan komersil $85 \%$ dengan penambahan cacing sutra (Tubifex sp.) $15 \%$ (D) sebesar 76,67 \%, sedangkan nilai terendah terdapat pada perlakuan pemberian pakan komersil $100 \%$ tanpa penambahan Tubifex sp. $5 \%$ (A) sebesar 61,68\%. 


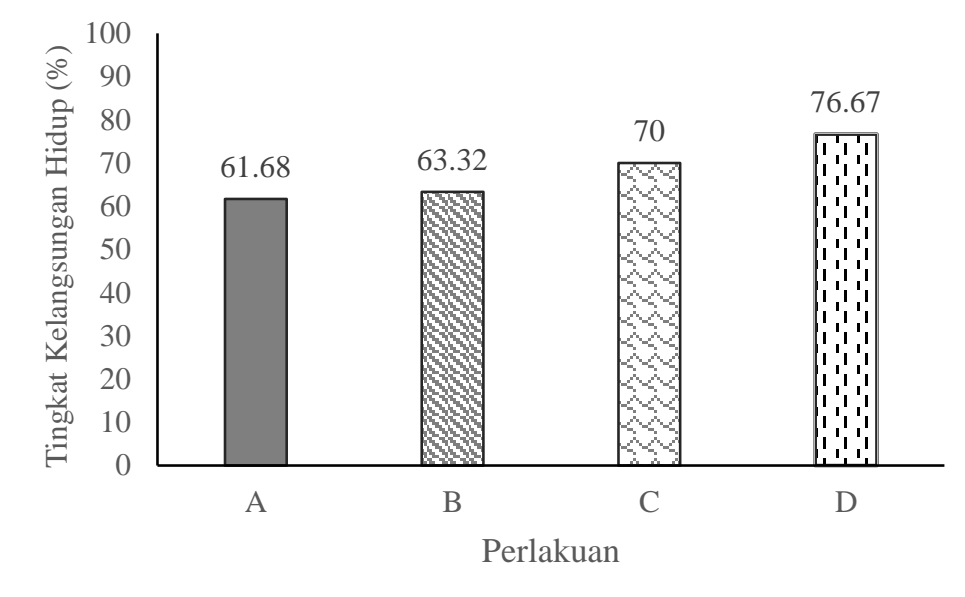

Gambar 4. Tingkat kelangsungan hidup benih patin selama pemeliharaan. Ket : Huruf superscript yang berbeda menunjukkan perbedaan yang nyata antar perlakuan pada taraf 5\% uji Duncan

Kelangsungan hidup dipengaruhi oleh faktor internal dan eksternal, dimana faktor internal dipengaruhi oleh resistensi penyakit, pakan dan umur, sedangkan faktor eskternal dipengaruhi oleh padat tebar, penyakit serta kualitas air (Effendi, 2002). Hasil penelitian menunjukkan bahwa pemberian pakan komersil dengan penambahan Tubifex sp. sebagai pakan tambahan tidak berpengaruh nyata terhadap kelangsungan hidup benih patin. Kelangsungan hidup patin selama penelitian lebih dipengaruhi oleh kemampuan adaptasi benih pada awal pemeliharaan. Kematian benih patin cenderung terjadi pada minggu pertama pemeliharaan karena benih belum mampu beradaptasi dengan lingkungan yang baru. Tingkat kelangsungan hidup tertinggi pada perlakuan D diduga karena kualitas air lebih stabil dengan pemberian pakan tambahan Tubifex sp., sehingga tidak meninggalkan banyak sisa pakan di dasar wadah. Hasil penelitian ini sesuai dengan Idawati et al. (2018) yang menyatakan bahwa persentase kelangsungan hidup tertinggi dijumpai pada pemberian pakan cacing sutera karena kualitas air pemeliharan lebih baik dari perlakuan lainnya. Tingkat kelangsungan hidup terendah pada perlakuan A diduga karena pemberian pakan komersil lebih cepat menyebabkan kualitas air menjadi buruk apabila pakan tidak termakan oleh benih patin. Sisa pakan dan feses akan terakumulasi menjadi limbah organik yang dapat menurunkan kualitas perairan. Kamarudin et al. (2011) menyatakan bahwa pakan alami sangat membantu pada stadia pembenihan, dimana larva ikan baung yang diberi pakan buatan kelangsungan hidupnya rendah, tetapi jika diberikan bersamaan dengan pakan alami maka kelangsungan hidupnya lebih baik.

Secara umum, kualitas air sangat berpengaruh terhadap keberhasilan benih patin untuk mempertahankan kelangsungan hidupnya. Hasil pengukuran kualitas air menunjukan bahwa kualitas air selama pemeliharaan benih patin masih dalam batas kelayakan untuk kehidupannya. Suhu air selama penelitian berkisar 26,9$27,5^{\circ} \mathrm{C}$ dan $\mathrm{pH}$ air berkisar antara 7,02 - 7,59. Menurut BNSI (2009), ikan yang dipelihara dapat tumbuh dengan baik pada kisaran suhu $25-30{ }^{\circ} \mathrm{C}$ dan $\mathrm{pH}$ berkisar 
6,5-8,5. Kandungan Oksigen terlarut selama penelitian berkisar 5,74-6,8 mg/l. Kusdiarti et al. (2003) menyebutkan konsentrasi oksigen terlarut di atas $3 \mathrm{mg} / \mathrm{l}$ masih termasuk dalam bats toleransi ikan patin.

\section{Kesimpulan}

Pemberian pakan komersil dengan penambahan cacing sutra (Tubifex sp.) sebagai pakan tambahan berpengaruh nyata terhadap laju pertumbuhan bobot spesifik, pertumbuhan panjang mutlak dan rasio konversi pakan, namun berpengaruh tidak nyata terhadap tingkat kelangsungan hidup benih patin. Dosis terbaik untuk meningkatkan pertumbuhan benih patin adalah pemberian pakan komersil $85 \%$ dengan penambahan Tubifex sp. $15 \%$ sebagai pakan tambahan.

\section{Daftar Pustaka}

Arief, M., Manan, A., Pradana, C.A. 2015. Penambahan papain pada pakan komersial terhadap laju pertumbuhan, rasio konversi pakan dan kelulushidupan ikan sidat (Anguilla bicolor) stadia elver. Jurnal Ilmiah Perikanan dan Kelautan. 8 (2): 67-76.

Bintaryanto, B.W., T. Taufikurohmah. 2013. Pemanfaatan campuran limbah padat (Sludge) pabrik kertas dan kompos sebagai media budidaya cacing sutra (Tubifex sp). UNESA Journal of Chemistry. 2(1):1-8.

Badan Standarisasi Nasional Indonesia [BSNI]. 2009. SNI No.7550:2009 Produksi Ikan Nila (Oreochromis niloticus Bleeker) Kelas Pembesaran di Kolam Air Tenang. Badan Standardisasi Nasional Indonesia. Jakarta.

Bokings, U.L., Koniyo, Y., Juliana. 2017. Pertumbuhan dan kelangsungan hidup benih ikan patin siam (Pangasius hypophthalmus) yang diberi pakan buatan, cacing sutra (Tubifex sp.) dan kombinasi keduanya. Jurnal Ilmiah Perikanan dan Kelautan. 5 (3): 82 -89.

Darmawan, J., Tahapari, P., Pamungkas, W. 2016. Performa benih ikan patin siam Pangasianodon hypophthalmus (Sauvage, 1878) dan pasupati (Pangasius sp.) dengan padat penebaran yang berbeda pada pendederan sistem resirkulasi. Jurnal Iktiologi Indonesia. 16 (3): 243-250

Effendie MI. 1997. Biologi Perikanan. Yayasan Pustaka Nusantara. Yogyakarta. $163 \mathrm{hlm}$.

Effendie. 2002. Telaah Kualitas Air. Kanisius. Yogyakarta.

Hadinata, F. 2009. Pembenihan ikan patin Djambal. Balai budidaya Jambi. Ds. Sungai Gelam Kecamatan Kumpeh Ulu Kabupaten Muaro Jambi.

Hanief, M. A. R. Subandiyono, Pinandoyo. 2014. Pengaruh frekuensi pemberian pakan terhadap pertumbuhan dan kelulushidupan benih tawes (Puntius javanicus). Journal of Aquaculture Management and Technology. 3(4): 6774.

Huisman, E.A. 1987. Principles of Fish Production. Wageningen: Departemen of Fish Culture and Fisheries, Waganigen. 170p. 
Idawati, Defira, C.N., Mellisa, S. 2018. Pengaruh pemberian pakan alami yang berbeda terhadap pertumbuhan dan kelangsungan hidup benih ikan patin (Pangasius sp.). Jurnal Ilmiah Mahasiswa Kelautan dan Perikanan Unsyiah. 3 (1): 14-22.

Jusadi, D., Anggraini, R.S., Suprayudi, M.A. 2015. Kombinasi cacing Tubifex sp. dan pakan buatan pada larva ikan patin (Pangasianodon hypophthalmus). Jurnal Akuakultur Indonesia. 14 (1): 30-37.

Kamarudin MS, Otoi S, Saad CR. 2011. Changes in growth, survival and digestive enzyme activities of Asian redtail catfish Mystus nemurus larvae fed on different diets. African Journal of Biotechnology 10: 4.484-4.493.

Kusdiarti, H.M., Yunus M., Insan., Suhenda, N Dan Prihadi, T.H 2003. Penentuan kriteria Kualitas air Berdasrkan umur dan ukuran ikan jambal (Pangasius djambal). Prosiding Seminar Hasil Riset BRPBAT tahun 2003. 21-34.

Mahyuddin.2008. Agribisnis Ikan Lele Dumbo. Gramedia Pustaka Utama. Jakarta. $171 \mathrm{hlm}$

Muchlisin, Z.A., F. Afrido, T. Murda, N. Fadli, A.A. Muhammadar, Z. Jalil, C. Yulvizar. 2016. The Effectiveness of Experimental Diet with Varying Levels of Papain on The Growth Performance, Survival Rate and Feed Utilization of Keureling Fish (Tor tambra). Biosaintifika, 8(2): 172-177.

Rachmawati , D. dan Samidjan I. 2013. Efektifitas subtitusi tepung ikan denga tepung maggot dan pakan buatan terhadap pertumbuhan dan kelulus hidupan ikan patin (Pangasius). Jurnal Saintek perikanan. 9 (1): 62-67.

Ricker WE. 1979. Growth Rate and Models, p : 678 - 774. In: Hoar WS, Randall DJ and Brett JR , Editor. Fish Physiology. Volume ke-8. New York (GB): Acad Pr.

Saparinto, C., Susiana, R. 2014. Panduan Lengkap Budidaya dan Sayuran dengan Sistem Akuaponik. Lily Publisher. Yogyakarta. $114 \mathrm{hlm}$.

Saputra, I., Putra, W.K.A., Yulianto, T. 2018. Tingkat konversi dan efisiensi pakan benih ikan bawal bintang (Trachinotus blochii) dengan frekuensi pemberian berbeda. Journal of Aquaculture Science. 3 (2): 170-181.

Zonneveld, N. E., Husiman, A., \& Bond, J. H., 1991. Prinsip-prinsip Budidaya Ikan. PT. Gramedia Pustaka Utama. Jakarta. 318.

Zarkasih, M.H, Eriyusni, Leidonald, R. 2015. Pengaruh Pemberian Cacing Sutera (Tubifex sp.) dan Keong Sawah (pila ampullaceal) Terhadap Pertumbuhan Ikan patin (Pangasius sp.) [Skripsi]. Fakultas Pertanian Universitas Sumatera Utara. Medan. 